\title{
THE RHETORIC OF ANTHROPOLOGY: A READING OF THE LANDSCAPE CHAPTER IN COMING OF AGE IN SAMOA ${ }^{1}$
}

Miriam Dempsey Page

THE ETHNOGRAPHER WRITES in terms of relationships-with the culture in question, with a potential reader, with the text itself. Because of these relationships, the accumulated data pose two main rhetorical problems. The anthropologist feels the responsibility for ordering the field notes so that the reader can make some sense of what the culture is like; however, this normalizing rhetoric only partially reflects the culture (and, as some have argued, may, in fact, distort it). The ethnographer has to find other rhetorical means by which to engage the spirit of the people.

In The Realm of Rhetoric Chaim Perelman suggests that the rhetoric of any field should employ the discursive means necessary to fully make the case. ${ }^{2}$ It seems plausible, then, that a popularizing and experimental rhetoric like Margaret Mead's in Coming of Age in Samoa ${ }^{3}$ would draw on more than logical analysis in order to tell the story. In this pioneering ethnography, ${ }^{4}$ published in 1928 , Mead does more than normalize data. She also looks to poetics and visual art. The ethnography is cast overall in the analytical voice, particularly noteworthy in Mead's concern with methodology in the elaborate set of appendixes. In one unusual chapter, however, (Chapter two, entitled, "A Day in Samoa") Mead assumes the roles of poet, dramatist, storyteller, and landscape artist instead of that of the analyst that she prefers elsewhere in the text. The chapter is lyric and seems in one sense to be a prose poem or in another, a vignette, or even perhaps a one-act play, closely observing unities of time and place. Mead's apparent urge, however, to enfold the action of a daily cycle into the colors, sights, sounds, smells, and feel of a lush Samoan setting turns the dramatic twenty-four hour spectacle-from Samoan dawn to 
Samoan dawn-into an unforgettable landscape. By the 1920's landscape art had evolved from idealized scenes of natural beauty to conceptualized human landscapes, ${ }^{5}$ but the picture here is even more. It is the life it speaks of, suggesting voices, relationships, an intimacy with the Samoan people. Mead writes:

The life of the day begins at dawn, or if the moon has shown until daylight, the shouts of the young men may be heard before dawn from the hillside. Uneasy in the night, populous with ghosts, they shout lustily to one another as they hasten with their work. As the dawn begins to fall among the soft brown roofs and the slender palm trees stand out against a colourless, gleaming sea, lovers slip home from trysts beneath palm trees or in the shadow of beached canoes, that the light may find each sleeper in his appointed place. Cocks crow, negligently, and a shrillvoiced bird cries from the breadfruit trees. The insistent roar of the reef seems muted to an undertone for the sound of a waking village. . . . It is high noon. The sand burns the feet of the little children, who leave their palm leaf balls and their pin-wheels of frangipani blossoms to wither in the sun, as they creep into the shade of the houses. . . . A white-clad, ghostly throng will gather in a circle about the gaily lit house, a circle from which every now and then a few will detach themselves and wander away among the trees. Sometimes sleep will not descend upon the village until long past midnight; then at last there is only the mellow thunder of the reef and the whisper of lovers, as the village rests until dawn. (pp. 11, 13, 15)

This mood continues for the extent of the four and one-half page chapter, creating a rich texture of experience on a Samoan canvas. The lyrical attitude is Mead's way of moving back to that source, or wellspring, of Samoan experience too elusive for the analytical eye. Mead's detractors have argued that the portrait is romanticized, influenced perhaps by the idealized views of her young informants or perhaps by travel reports creating a rosy picture of a paradise ${ }^{6} \mathrm{Her}$ interest in painting would have led her also, no doubt, to the idyllic works of Gauguin as she was reading and researching widely about Samoa in the two or three years prior to her work there, a point she mentions in Blackberry Winter. In any case, the chapter emerges as a vibrant landscape, a mobile field, a "day" of Samoan mood and presence and history. It is for this pioneering attempt to enter into the experience of a strange culture, regardless of how partial or perhaps distorted the view, that Mead is to be commended here. This is not to suggest that the analytical voice does not also engage the life experience of the Samoans. Mary Catherine Bateson, Mead's daughter and a noted anthropologist herself, argues that statistics and other analytical modes do indeed have their place in writing the life experience of people. ${ }^{7}$ But she recognizes, as I do, that they are not all in composing ethnography.

The position of the landscape chapter suggests Mead's need to turn to more than analysis to write the Samoan story. She begins with a lengthy introduction she calls Chapter one in which she explains her reasons for the project: to see whether problems confronting adoles- 
cent girls in Western civilization are the same at this life stage in any society or whether their problems are the result of the pressures of modern life; and, a larger aim, to study the effects of education on human personality. Chapter two, "A Day in Samoa," follows, reading like an overture to chapters three to twelve that, however, discuss in some detail the Samoan girl's education, her place in the household and community, and the evolution of her rites of passage from birth to old age. What seems to be two beginnings is Mead's skillful management of perspectives. The Samoan section is embedded in the larger frame of the ethnography. Following Mead's introductory discussion of her comparative plans for study, the landscape chapter ushers the reader into the interior-from the outer perspective to a Samoan world of crimson jelly fish, burning sand at high noon, roast pig over a smouldering fire, sleepy huts beside a lazy Samoan sea, gossipy elders filling idle moments, and the inevitable secret lovers on dark hillsides, with whom Mead, curiously, begins and ends her story of the Samoan day. Chapters three to twelve, resuming the observer's voice, begin the return to the outside, and lead finally out again in two culminating chapters discussing the comparative effects of education on youth. An ironic footnote here is that the last two chapters were added at her publisher's insistence, ${ }^{8}$ but Mead apparently concurred, never excluding them from the subsequent editions of the text.

In creating a journey motif Mead is inviting the reader to explore with her the role of "participant-observation." " As Derek Freeman has remarked in his recent controversial book attacking Mead's methods, ${ }^{10}$ however, and as Mead herself says in the ethnography, ${ }^{11}$ her position in the Samoan community was somewhat "neutral." Although convenience and a better diet are the reasons she gives for not living in a native house, she might also have been to some degree apprehensive. As an anthropologist, she was experimenting. She was young (in her early twenties), and the field was young. Moreover, the caution of her mentor, Franz Boas, in protecting her might have made her wary of going to live among a strange society on the other side of the world. She was also a single young woman in a strange environment, and social protocol more appropriately dictated her staying with the mission pastor or a government official, suitable chaperons. Jean Elshtain in her article, "Coming of Age in America: Why the Attack on Margaret Mead?” writes:

There is no doubt that the pioneering research Mead conducted fifty-eight years ago poses problems: the reliability of her informants, her sketchy knowledge of the language, and her decision not to live in a native household, among others. A contemporary cultural anthropologist would do things differently. But though 
Freeman belabors these points, they hardly constitute a knock-down argument against a researcher creating or helping to create a new field of inquiry. ${ }^{12}$

Mead's scientific perspective was problematic from the point of view of current ethnographic practice, but her exhaustive study (as far as she knew) of all of the girls of three villages and the obvious bias that she admits to, seen mainly in the warm anecdotes that she tells of her experiences with the Samoans, make her vantage point something more than "neutral."

Mead's turning to art corroborates her apparent urge to learn what it is to be Samoan. The careful tables charting family structure and adolescent girls' menstruation cycles, for example, provide data but do not catch the sounds of stealthy lovers on dark hillsides or the cries of "Tolofa! Tolofa!" as the villagers greet each other at the beginning of a new day. Because Coming of Age in Samoa is an early ethnography, Mead is exploring for herself the relationship between "participant" and "observer," but the invitation to her reader to share in discovering and invoking an outer and inner vision for understanding the Samoans is unmistakable.

It is more than representation that Mead as artist is suggesting here. She invites a Samoan presence through the immediacy of art and the reflective nature of language. Later she was to comment in $A n$ Anthropologist at Work: "Writing is sequential, but landscape is all at once."13 Her use of language here is poetic, close to that part of human experience that eludes naming; but the visual imagery amplifies that experience even more and returns to the essence of what it is to be Samoan in a way that words cannot. These Samoans speak for themselves in this landscape. The artist steps aside as the irresistible images compel us to enter into the experience. She writes:

The whole village, sheeted and frowsy, stirs, rubs its eyes, and stumbles towards the beach. . . . Many of those who have retired to sleep, drawn by the merry music will wrap their sheets about them and set out to find the dancing. (pp. 11, 14-15)

Mead is positing here in her role as story-teller a contingent relationship between understanding and writing, participation and observation, intimacy and retrospect.

In the landscape chapter, the writer and reader are not detached observers, but are quickly drawn into the alternating rhythms of this sleepy and busy Samoan day. Though it is a time and place set apart by its strangeness, it speaks of human action, community, discoursea dialogue flowing out of human personality that cannot always be contained in neat wineskins (old or new)-or, in fact, analyzed under a microscope. She writes:

A second time, the sleeping people stir, roused perhaps by the cry of "boat," resounding through the village. The fishermen beach their canoes, weary and spent from the heat, in spite of the slaked lime on their heads, with which they have 
sought to cool their brains and redden their hair. The brightly coloured fishes are spread out on the floor, or piled in front of the houses until the women pour water over them to free them from taboo. . . . Two kinsmen, or a chief and his councillor, sit and gossip over the day's events or make plans for the morrow. (pp. 13, 14)

Mead would understand the Samoans here. The landscape is not a canvas to remain aloof from, an object only to look at, admire, or wonder about. ${ }^{14}$ This "picture" is lived experience that beckons, experience to be entered, to be shared. It speaks of story and brings an unmistakable energy to the text. To try to compose the story of a culture apart from their own perspective, according to Charles Taylor in his essay, "Interpretation and the Sciences of Man," 15 is to distort any efforts at telling their story.

Mead turns to visual art here in order to further get the inside story. She is not just a reporter. The landscape chapter, combining the recursiveness of visual art and language, opens the way for dialogue with the Samoans. Mead is suggesting here a common ground on which the Samoans and Western civilization can learn from each other. $^{16}$ This dialogue of the human spirit knows no language barriers:

From the other end of the village comes a long drawn-out, piercing wail. A messenger has just brought word of the death of some relative in another village. Half-clad, unhurried women, with babies at their breasts, or astride their hips, pause . . . to wonder who is dead. (p. 12)

The aporias, or puzzlements, of birth, life, death, and sexuality are implicit here as well in this emblematic "day" on canvas. Mead knew that the reader, who comes to the Samoans through the commonality of human experience, is as much a part of the composing of the ethnography as those with whom the story originated.

The story, moreover, can only be approximate. Much remains unspoken because of the limitations of getting the inside view and because of the shifting nature of disclosure as the writer and reader invite the story. Light and shadow are pervasive in the landscape as they move in and out of the clearing:

As the sun rises higher in the sky, the shadows deepen under the thatched roofs. . . . It is high noon. . . . Finally the sun sets, in a flame which stretches from the mountain behind to the horizon on the sea; the last bather comes up from the beach, children straggle home, dark little figures etched against the sky; lights shine in the houses, and each household gathers for the evening meal. . . . Half the village may go fishing by torchlight and the curving reef will gleam with wavering lights. . . . The white smoke hardly visible against the paleness of the dawn ... (pp. 11-14) ${ }^{17}$

The story is suggestive, then. It is not fixed, but speculative, processual-in short, rhetorical and dialogical. Writer, reader, and culture collaborate in the telling of the story, working out the text, 
living it out, an outer-inner interaction engaging the life that becomes the text. It is a community of sharing that calls forth the text.

Mead is acutely aware of her readers, as she notes in the prefaces to the several editions of Coming of Age in Samoa. She is quick to point out in her 1973 preface that the text was written in terms of a reader of the 1920's - thus, her reason for particular emphases. My point here, however, is also her sense of continuing joint authorship, the text re-creating itself with the active role she sees for the reader of every new generation in the composing process. And her key concern, I should add, is the modern and literate Samoan reader, who has also come to the text.

What the ethnographer and his or her reader bring to the composing of the text cannot be ignored. Moreover, beginning with the outer perspective, as Mead does, intensifies going inside and returning to the outside. Neither the ethnographer, nor the reader, can ever leave the outsider's place behind if the story is to be told, and once he or she has been inside is never the same on the return to compose the textwhat Renato Rosaldo calls a "telling closeness," 18 and that, I would add, culminates in self-understanding. ${ }^{19}$ Of course, what I am suggesting is ideal. Many remain aloof and neutral reporters. Most never attempt a "landscape." To pose the presence of a people on the page, as Rosaldo observes, is a question of validity, not of normalization, which can by virtue of its distance be even parodic (pp. 7, 9). It would seem that the "telling" of human experience deserves more.

\section{NOTES}

1 This article is based on a paper presented at the Conference on College Composition and Communication, March 22, 1985, Minneapolis, Minnesota.

2 Chaim Perelman (trans. William Kluback), The Realm of Rhetoric, originally published as L'Empire rhétorique: rhétorique et argumentation (Notre Dame: University of Notre Dame Press, 1982).

3 Margaret Mead, Coming of Age in Samoa: A Psychological Study of Primitive Youth for Western Civilization (New York: William Morrow and Company, 1928, 1955, 1961). Subsequent references to Coming of Age in Samoa will be indicated by the page number in the text.

4 I use "ethnography" here to mean ethnographic writing. As Bronislaw Malinowski in Argonauts of the Western Pacific (1922) composes his account of Trobriand culture through a discussion of the kula system, one aspect, but central to an understanding of the Trobriand Islanders, Margaret Mead engages Samoan life by focusing on the education of the adolescent girl in that culture.

5 See "Landscape in Art," Encyclopedia of World Art, Volume IX (New York: McGraw-Hill Book Co., 1964), 2-49; “Gauguin, Paul,” Volume VI, 39-43.

6 The letters of Henry Adams were among the early travel reports of the exotic South Sea paradise. His mellifluous prose is strikingly similar to that in Mead's landscape chapter. 
7 Mary Catherine Bateson, With a Daughter's Eye: a Memoir of Margaret Mead and Gregory Bateson, (New York: William Morrow and Company, 1984).

8 Ibid.

9 George W. Stocking, Jr., ed., Observers Observed: Essays in Ethnographic Fieldwork, History of Anthropology, (Madison: University of Wisconsin Press, 1983), Volume I, 7.

10 Derek Freeman, Margaret Mead and Samoa: The Making and Unmaking of an Anthropological Myth (Cambridge, Mass. and London: Harvard University Press, 1983).

11 See also her discussion of her days in Samoa in Margaret Mead, Blackberry Winter: My Earlier Years (New York: Simon and Schuster, 1972), 137-154.

12 Jean Bethke Elshtain, "Coming of Age in America: Why the Attack on Margaret Mead?” The Progressive, Volume 47, Number 10 (October, 1983), 34.

13 Margaret Mead, ed., An Anthropologist at Work: The Writings of Ruth Benedict (Boston: Houghton Mifflin, 1959), xxi.

14 I refer to the "picture" theory of meaning in the early Wittgenstein, Tractatus Logico-Philosophicus.

15 Charles Taylor, "Interpretation and the Sciences of Man," Understanding and Social Inquiry, eds. Fred R. Dallmayr and Thomas A. McCarthy (Notre Dame: University of Notre Dame Press, 1977), 101-131.

16 See Peter Winch, "Understanding a Primitive Society," Understanding and Social Inquiry, 159-188, for his discussion of the need for finding such a commonality.

17 See Martin Heidegger, On the Way to Language and "Language" in his Poetry, Language, and Thought for his discussion of "appropriation" (inviting presence) and the shifting nature of concealment and disclosure in composing presence. Walter Biemel's Poetry and Language in Heidegger (pp. 82-99) is helpful in seeing the development of Heidegger's thought.

18 Renato Rosaldo, "Where Objectivity Lies: The Rhetoric of Anthropology." Paper presented at the University of Iowa Humanities Symposium; theme: The Rhetoric of the Human Sciences, Iowa City, Iowa, March 28-31, 1984, 3.

19 Paul Ricoeur notes "self-understanding in front of the work" (my italics), "Hermeneutical Function of Distanciation," in Paul Ricoeur, Hermeneutics and the Human Sciences, ed. and trans. John B. Thompson, 142-144. I question this description as limiting. Self-understanding emerges from the rhetoric of inquiry that composes the text. 